\title{
環境に配慮した金属調フィルムの加飾展開
}

\author{
山田隆一 ${ }^{\mathrm{a}}$ \\ ${ }^{\mathrm{a}}$ 秼桘屋 $($ T 468-8330 愛知県名古屋市中区上前津 2-9-29)
}

\section{Environmentally Friendly Metal Looking Film of Decorative Development}

\section{Ryuichi YAMADA ${ }^{\mathrm{a}}$}

${ }^{a}$ Tsuchiya Co., Ltd.(2-9-29, Kamimaezu, Naka-ku, Nagoya, Aichi 460-8330)

Keywords : Metal Looking Film, Deposition, Sputtering Film, Insert Molding, Flexible Decorative Mark

\section{1.はじめに}

人類と金属との歴史は, $\mathrm{BC} 3000$ 年頃エジプトにて金は装 飾品としてファラオへ献上され，また BC1800 年頃にはメソ ポタミア地方を支配したヒッタイト人が鉄の精製技術を発見 し鉄器時代が始まった。鉄, 銀, 青銅, 金は装飾及び生活の 一部として使用され，日本でも青銅が銅鐸やコインとして使 用され中国から送られた漢倭奴国王印(金)，また仏教伝来と ともに奈良東大寺の大仏 (盧舎那仏)では金, 水銀のアマルガ ムにて金めっきを施した表面処理 (鍍金)が実施された。

中世ヨーロッパでは, 高価な金を得るために錬金術で人工 的に金を精錬しようとする技術が有機合成の幕開けとなった。

金属表面処理は装飾・腐食性・耐熱性・摩耗性向上及び金 属レベルの光学特性(可視光反射率)を得るためめっき, アル マイト処理が以前から活用され, 一例として電気分解反応を 応用した鉄への亜鉛めっき(トタン), スズめっき(ブリキ)や 銀鏡反応を利用してガラスに銀を析出させる鏡, アルミへの 陽極酸化(アルマイト), ガラス質皮膜被覆 (ホーロー加工) が 工業製品に応用されてきた。

代表的な処理方法であるめっきは電気めっき, 無電解めっ きにより， $\mathrm{Au}, \mathrm{Ag}, \mathrm{Ni}, \mathrm{Cr}, \mathrm{Cu}, \mathrm{Zn}$ などの金属が, 金属・ 樹脂に薄膜として形成され防錆, 摩耗, 耐熱, 表面硬度の向 上, 電磁波シールド性及び装飾用途に工業分野では活用され てきたが, 昨今では環境問題, 欧州 REACH 規制 (6 価クロム), および大型部品のつきまわり, 治具費用, 成形一めっきプロ セスの横持ちの背景により代替工法・材料が検討されてきた。 6 価クロム代替として 3 価クロムめっきも技術的に確立実用 化されまためっき以外の表面処理, 金属外観仕上げ工法とし て蒸着, スパッタ(イオンプレーティングを含む), 金属微細 フレーク顔料を分散した塗料・インクや蒸着加工を応用した ホットスタンプ箔が化粧品容器, 化成品, OA 関連含め採用 され加飾材料のバリエーションも拡大した。

こういった成形品へのダイレクト金属表面処理の他に，金 属調フィルムを介在した樹脂成形工法がここ数年来急速に多 用化し実用化されてきた。その背景にはフィルムコストダウ
ン, 工程合理化, 環境対応, 品質の安定化, 従来の射出成形 機以外の設備投資の少なさ, フィルム加飾技術・材料の各社 の取組みが挙げられる。

\section{2. 金属調フィルム概要}

\section{1 樹脂フィルム}

従来蒸着は主に紙，PET フィルムが大半を占めるが，目的 用途に応じフィルムが選択できる。PET フィルムでは従来延 伸 PET フィルムへの蒸着が一般的であり延伸不可であった が, 成形延伸用途も開発された。最近, アクリル・ウレタン・ $\mathrm{PVC} \cdot \mathrm{PC} \cdot$ フッ素・オレフィンフィルムへの蒸着も多数見 受けられる。耐候性に優れるアクリルは, 反面耐溶剤性・耐 衝撃性・柔軟性に課題があるが, 相溶性のあるゴムソフトセ グメント配合により透明性を維持し可撓性は向上されている。 PET フィルムは耐熱性に優れるが耐加水分解性に劣り, PVC フィルムはコスト, 性能バランスには優れるが欧州 REACH 規制非該当の可塑剂選定がポイントであり, 添加剤ブリード による密着低下対応としてプライマー層を設け蒸着を実施す るケースが多い。フッ素フィルムは含有フッ素数により PVF, ETFE, PVDF, DFA フィルムがあり耐熱・耐候性に優れるが, フィルム表面張力が低いためコロナ，プラズマ処理等の表面 改質が必要であるが, 昨今 $\mathrm{PVDF} /$ アリリルアロイフィルム も実用化されている。適用環境に応じたフィルム選択が必要 である。

\section{2 フィルム製膜方法}

熱可塑性樹脂を熱や溶剤などで低粘度溶融状態にした押出 し製膜やカレンダー製膜, インフレーション製膜, キャスティ ング製膜等の製膜方法にてフィルム化することができ, 目的, 用途に応じて各製膜方法が選択される。図 1 に概要を示す。

その際ロット, 平滑性, 透明性, 収縮性, コスト, 耐環境 ストレス (光・熱・水)を考慮し, 安定剂 (UVA, HALS, 熱 安定剂, 酸化防止剂) や加工助剂 (増粘防止, レベリング剂, ブロッキング防止)の処方も行う。その後, インライン加工 として 1 軸, 2 軸延伸, 密着向上 (プライマーコート, コロ ナ処理，プラズマ処理)の加工も実施される。 


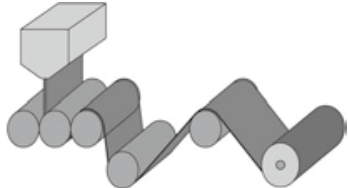

押出し法

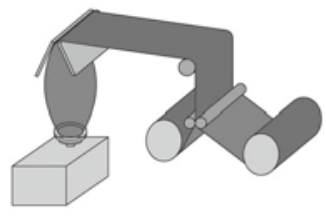

インフレーション法

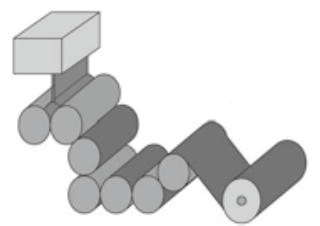

カレンダー法

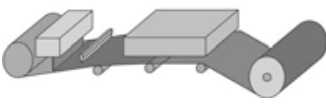

キャスティング法

\begin{tabular}{|l|l|c|c|c|c|c|}
\hline \multicolumn{2}{|l|}{ 製膜方法 } & 厚み $(\mu \mathrm{m})$ & ロット & コスト & 平滑性 & 収縮性 \\
\hline \multirow{2}{*}{ 押出し法 } & Tダイ法 & $10 \sim$ 数 $\mathrm{mm}$ & $\times$ & $\bigcirc$ & $\bigcirc$ & $\Delta$ \\
\cline { 2 - 8 } & インフレーション法 & $10 \sim 50$ & $\times$ & $\bigcirc$ & $\Delta$ & $\Delta$ \\
\hline \multirow{2}{*}{ カレンダー法 } & $50 \sim 500$ & $\Delta$ & $\bigcirc$ & $\bigcirc$ & $\bigcirc$ \\
\hline キャステイング法 & $10 \sim 50$ & $\bigcirc$ & $\times$ & $\bigcirc$ & $\bigcirc$ \\
\hline
\end{tabular}

図1 各種フィルム製膜方法概要図と特徵

・押出し法：押出機の先端に $\mathrm{T}$ ダイと呼ばれる直線状の リップを持つ金型を設置し平たく材料を押出して連続的 に製膜する。

・カレンダー法：あらかじめ溶融状態に加熱した熱可塑性 樹脂を複数のローラー(カレンダーロール)に挟んでフィ ルム状に圧延し製膜する。

・インフレーション法：押出機の先端にリングダイスと呼 ばれるリップを持つ金型を設置し，チューブ状に材料を 押し出して連続的に製膜する。

・キャスティング法：樹脂を溶媒に溶解させ流動性を持た せた溶液をドラム工程フィルムに流延し製膜する。特徴 は溶媒分散での溶融化のため熱履歴の伴わない製膜によ り添加剂配合の設計自由度, 透明性, 収縮性, 厚み精度 に優れ付加価值の高いフィルムが可能であるがコストパ フォーマンスに劣る。

\section{3 二次加工}

\section{3. 1 印刷}

使用する版の種類によりオフセット，グラビア，スクリー ン印刷があり印刷ロット, 解像度, 耐光性, 摩耗性などの耐 久性面から選択されるが車載用途ではグラビア，スクリーン 印刷が主に活用される。ここ数年来従来の製版使用のアナロ グ印刷から版レス小ロット多品種対応の面よりデジタル印刷 の普及が目覚しく特にインクジェット印刷においては延伸性, 耐光性, 摩耗性に優れた UV-LED 硬化インクが害用化され ている。これらの印刷工法の概要を表 1 に示す。

\section{3. 2 接着}

異種フイルムの多層化ラミネート用及び成形樹脂への接着 として熱ラミネート，イソシアネート架橋剤を使用した二液 硬化型接着剤, 反応性ホットメルト接着剤, アクリル酸エス テル樹脂を主とした感圧接着凨が主に使用される。低極性樹
表 1 各種印刷方法の概要

\begin{tabular}{|c|c|c|c|c|c|c|c|}
\hline \multirow{2}{*}{ 工法 } & \multirow{2}{*}{ ロット } & \multirow{2}{*}{$\begin{array}{l}\text { 製版 } \\
\text { コスト }\end{array}$} & \multirow{2}{*}{ 解像度 } & \multirow{2}{*}{$\begin{array}{l}\text { リード } \\
\text { タイム }\end{array}$} & \multicolumn{3}{|c|}{ 印刷品質 } \\
\hline & & & & & 耐光性 & 耐摩耗性 & 延伸性 \\
\hline オフセット & 大 & 小 & 高 & 中 & $\triangle$ & $\triangle$ & $\times$ \\
\hline グラビア & 大 & 大 & 高 & 大 & $\triangle$ & $\triangle$ & $\mathrm{O}$ \\
\hline スクリーン & 小 & 小 & 中 & 中 & (a) & (2) & 0 \\
\hline インクジェット & 微～小 & $\begin{array}{l}\text { 無 } \\
\end{array}$ & 高 & 小 & $\bigcirc$ & 0 & 0 \\
\hline
\end{tabular}

脂への接着は，塩素化 PP，無水マレイン酸変性樹脂をプラ イマーとして使用されるケースがある。接着はフィルム・接 着剂の表面張力・SP 值 (溶解性パラメーター)により接着剂 樹脂は選択される。

2. 3.3 表面加工

表面に本圭, 皮革, カーボ調などのエンボス加工を施す場 合，カレンダー・押出し製膜後エンボスロールにてフィルム 表面に凸凹を付与またキャスティングの場合はエンボス工程 フィルムを活用しパターンを転写する工法が一般的である。

2. 3. 4 蒸着・スパッ夕

使用金属として従来から $\mathrm{Al}$ が主体で $\mathrm{Cr} ， \mathrm{Ni} ， \mathrm{Au} ， \mathrm{In} ， \mathrm{Cu}$ 及びステンレス，八ステロイ，モネル等金属アロイが一般的 に使用されてきたが帯電防止・電波透過性の面から不連続島 状構造を形成しやすい In, Sn が携帯・モバイル部品への適 用も増加している。また In, Snの島状構造を利用して延伸 性が要求されるインサート, インモールド転写, 真空成形, 三次元熱被覆成形用の金属調フィルムでの利用も計られてい る。また昨今コスト面・金属外観・腐食性を考虑して In-Sn アロイでのスパッタも開発が進められている。

なお，最近金属を利用せず数種類の屈折率の異なる無機酸 化物による多層化スパッ夕を施し， $\mathrm{Au} ， \mathrm{Ti}, \mathrm{Cu}$ の金属外観 を有する表面処理や構造色発色の原理を応用してナノレベル 薄膜を 1000 層近く積層した金属レスで金属外観を有する フィルムも上市され腐食性, 電波透過性機能が必要とされる ミリ波レーダー，ブルートゥースにて採用事例がある。

\section{4 成形加飾工法}

樹脂成形として射出成形法, 押し出し成形法, ブロー成形 法, 真空成形法があり, 金属調外観付与としてめっき, スパッ 夕, 高輝度メタリック塗装，ホットスタンプ金属箔転写が従 来主流であったが加飾工程の合理化，ヘアーライン，スピン， サテン調などデザインニーズの多様化, グレードマネジメン 卜による小ロット多品種対応面より金属調フイルムを使用し たインサート成形，インモールド転写，三次元熱被覆による ラッピング加飾が車両，OA，住建分野での採用が増加して いる。

インサート成形は加飾フィルムを真空成形・圧空成形によ りプレフォーミングし製品部をトリミング後射出成形機のコ ア部にセットし溶融樹脂を注入し同時成形される。メリット としては大ロット生産向き, 接着信頼性が高く意匠再現性精 度がある。またプレフォーミング成形におき従来の圧空 $(2$ $\left.\sim 8 \mathrm{~kg} / \mathrm{cm}^{2}\right)$ に対し $10 \sim 20$ 倍の圧力にて成形する超高圧成 形も国内では普及し低温成形での意匠再現性，二軸延伸 PET, PI など難成形素材への適用も可能となった。デメリットと しては準備費として真空成形金型，トリミング型，射出成形 型が必要であり各型設計，マッチングなど高度な加工技術を 
必要とする。またインモールド転写はロール to ロールにて 加飾䇴フィルムを射出金型内にてフォーミングし射出成形す る工法であるが小ロット対応，絞り自由度で設計自由度が制 約される。

インサートなど同時成形に代わる加飾工法として，成形品 に加飾フィルムを熱と圧力で被覆する後加飾工法はここ数年 来急速に採用事例が増加している。従来の成形品をそのまま 活用し専用被覆成形機にて安価な受け治具のみの準備費で小 ロット多品種, デザインニーズ多様化に対応することが可能 で木目調, カーボン調, 皮革調, 幾何学パターンなどの加飾 パターン, 延伸性, 耐久性の高いフィルム素材, 接着荗も開 発され現在車載内装ガーニッシュ等で採用されている。加工 工程は成形品に熱被覆後レーザー, 超音波及び専用カッター などでトリミングされる。メリットは安価な準備費, 治具設 計による巻き込み形状の自由度, 加飾フィルムによる表現の 拡大があるが成形後の加工(トリミング, 巻き込み)での工数, 接着信頼性, 位置決め精度, フィルム厚みによる成形部品干 渉, 成形品の面品質, クリーンな成形環境が要求され各社技 術向上が計られている。昨今トリミング工程廃止としてフィ ルムレス転写仕様の加飾部材も開発されトリミングレスタイ プも上市され始めている。

\section{3. 金属調フィルムの開発}

\section{1 成形用金属調フィルム}

弊社は金属外観を有する成形用高耐久性フィルムを開発した。 自動車や家電, $\mathrm{OA}$ 製品, 携帯電話など身近な工業製品に は金属調外観の装飾品がよく使用されている。一般的工法と してめっき, スパッタ, 蒸着, 塗装が用いられ主事例として 金属美装化，防錆，コスト面より以前からめっきが広く利用 されてきた。めっき工法はいくつかの課題があり，(1)めっき 廃液は有害物質を含むため処理が必要(特に Cr めっき廃液の 六価 Cr は欧州 REACH 規制などの対象物質), (2)成形工程と めっき工程が別工程であるため工程が非合理的, (3)大型及び 複雑形状でのジグ設定，めっきつきまわり，(4)めっき色・塗 装色が限定されるためカラー自由度が低くめっき処理面への 塗装は経年劣化による耐久性に久ける，などが挙げられる。

弊社は従来技術のこれらの課題に取り組みめっき工程の代 替となる環境を配慮した「金属調成形体」の開発を手がけた。 成形体の構成を図 2 に示す。これは金属調フイルムと熱可塑 性樹脂シートを接着剂にてラミネートした積層体を真空成形 にて付形した金属調プラスチック成形体である。このプロセ スにより製品化した大型成型品は自動車販売店様店舗用看板

材料構成

\begin{tabular}{|c|c|}
\hline クリヤーコート & \multirow{2}{*}{$\begin{array}{l}\cdots \text { グロスコントロール } \\
\cdots \text { カラークリヤー調印刷 }\end{array}$} \\
\hline 着色層 & \\
\hline 透明高耐候フィルム & …高延伸性フィルム \\
\hline 金属蒸着層 & …高延伸性金属蒸着 \\
\hline 感圧型接着剂 & \\
\hline ABSシート(黒·白) & \\
\hline
\end{tabular}

として採用されている。

本開発材料，工法に置き換えることによりめっきプロセス 廃止での環境配慮・工程合理化が実現できオリジナル金属調 フィルムに弊社のコア技術である印刷技術の応用により加飾 自由度・耐候性・腐食性等耐久性向上も可能となった。

従来の金属調フィルムはポリエステル系フィルム基材に $\mathrm{Al}$ や $\mathrm{Cr}$ を真空蒸着したものが一般的であるが，外観がめっ き金属感と異なることや延伸性が低く成形後にフィルムの白 化や蒸着層のクラックが発生する課題があった。また耐久性 面でも耐候性や加水分解性に難があり $\mathrm{Al}$ 蒸着層が腐食し金 属外観の損失も発生する。

これに対し弊社の金属調フィルムは高耐久性・高延伸性を 持つ熱可塑性透明ウレタンフィルムに不連続な特殊金属粒子 を島状に配列蒸着した構造が特徵である。この熱可塑性ウレ タンフィルムは透明性に優れピンホール等の外観欠点が発生 しない高平滑を達成するため, 溶液流延法(キャスティング) 製法によりフィルム化される。

またこのフィルムは無黄変イソシアネート, 耐加水分解性 に優れるポリオール，重合度・架橋率を制御し可撓性を調整 する架橋剤・鎖延長剤を適正配合している。

併せて高延伸 - 高耐久に設計された感圧接着剂や表面処理 （インキ，クリヤー)を構成部材として選定しており高延伸性 インク・クリアーはウレタン系及び変性塩ビブレンド樹脂に 安定剂 (紫外線吸収剂), 加工助剤 (チクソ性・表面張力コン トロール剤)を配合しスクリーン印刷により均一に金属調 シートに約 $10 \mu \mathrm{m}$ 程度に塗布される。加工プロセスを図 3 に示す。またカラークリアインクによるシャンパンゴールド 調の反射特性を図 4 に, 成形品の事例を図 5 に示す。

この積層体は $250 \%$ 以上の高延伸性やめっき製品よりも優 れる耐腐食性を有し，また金属蒸着する際に粒子径や粒子間 隔，占有面積を制御することによりハーフミラー外観 (可視 光透過性)やめっきでは不可能な電波透過性の機能付与を実

加エプロセス

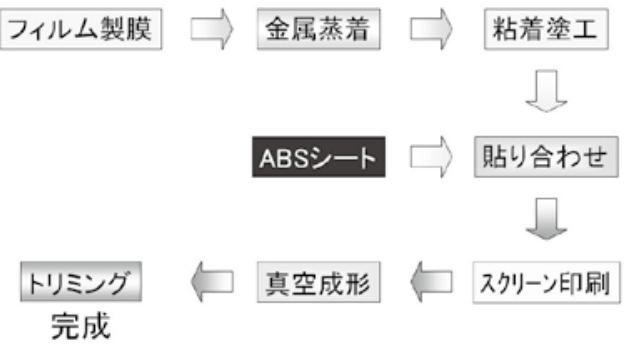

スクリーン印刷

貼り合わせ
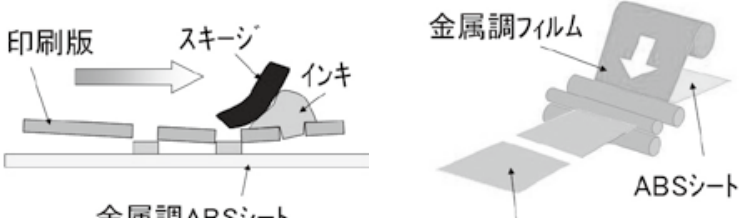

金属調ABSi゙ート 


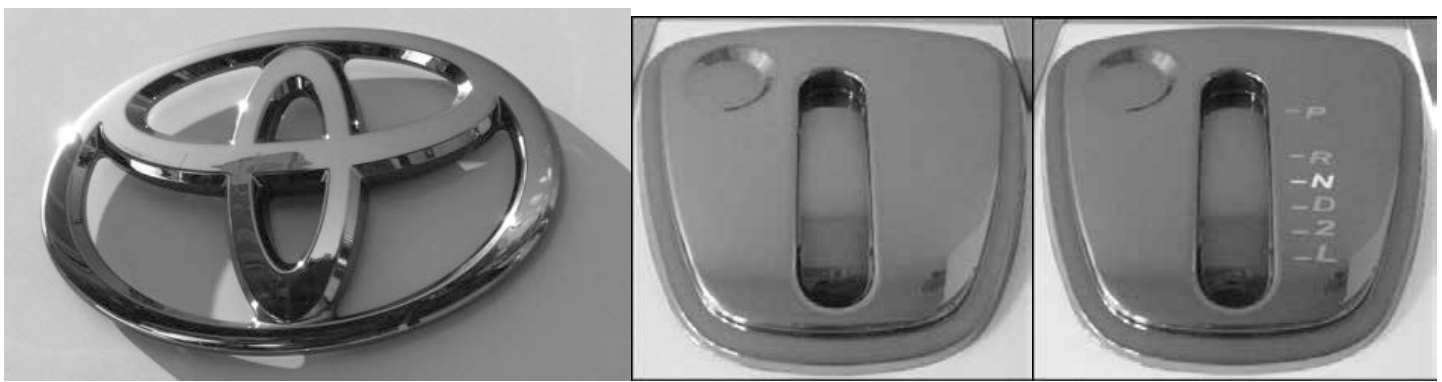

（非点灯） $\rightarrow$ (点灯時）

図 5 金属調フィルムによる成形品事例

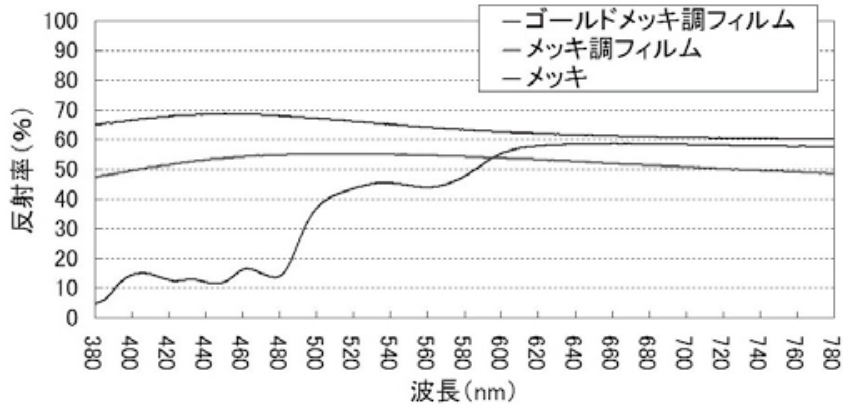

図 4 ゴールド調の反射特性

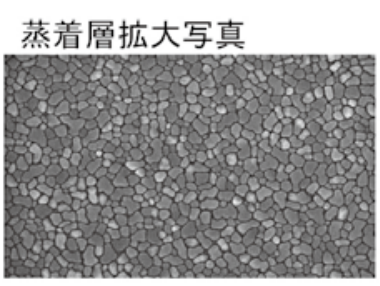

$$
\begin{aligned}
& \text { 粒子径 短径 } 30 \sim 50 \mathrm{~nm} \\
& \text { 長径 } 60 \sim 90 \mathrm{~nm} \\
& \text { 粒子間隔 } \quad 5 \sim 25 \mathrm{~nm}
\end{aligned}
$$

図 6 金属蒸着の様子 (SEM)

現している。金属蒸着の SEM を図 6 に示す。

真空成形用途以外にインサート成形，3 次元熱被覆成形が 加飾にも取り組まれ，特にオレフィン (PP-PE)へのめっきは, 密着信頼性, 低温一高温線膨張差, 成形時のソリ等の課題が あるため, オレフィン樹脂への金属調フィルムインサート成 形が一つのポイントである。開発した金属調フィルムと厚み $200 \mu \mathrm{m} \sim 500 \mu \mathrm{m}$ の押し出し成形した CPP（無延伸ホモポリ プロピレン)を接着処理としてコロナ処理を施しイソシア ネート硬化ウレタン系接着剤でドライラミネートを実施する。 このバッキング材としての CPP は射出成形での $200{ }^{\circ} \mathrm{C}$ に溶 融した PP 樹脂が同素材のため相溶化し接着信頼性の確保が 可能である。インサートプロセスを図 7 に示す。

\section{2 金属調マーク}

現在は開発金属調フィルムを使用した弊社オリジナル立体 軟質マーク「ハイボスカル ${ }^{\circledR} 」($ 図 8)などへ適用し, 自動車, 農機・建機, 家電, OA, 建材関係など多岐に渡る分野で採 用実績がある。

従来は $\mathrm{ABS}$ 射出成形品に $\mathrm{Ni}-\mathrm{Cr}$ めっきを施した車名マー

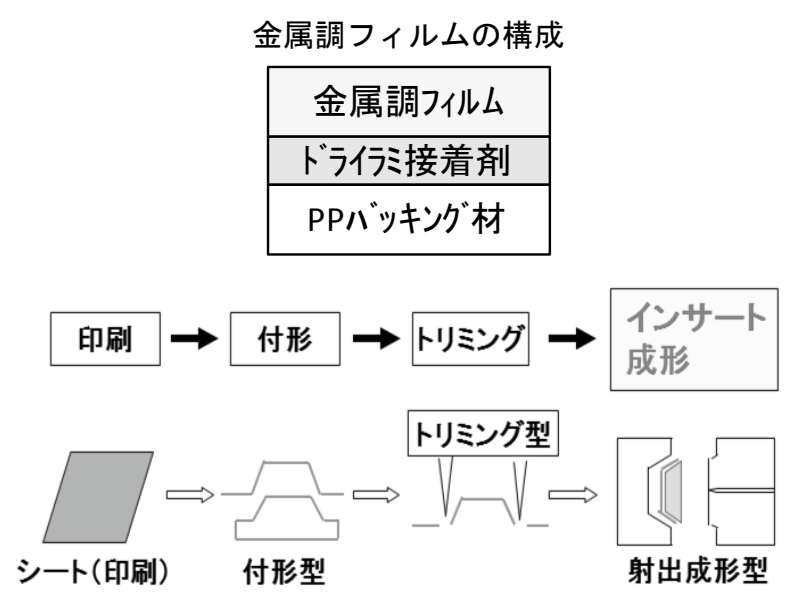

図 7 構成とプロセス

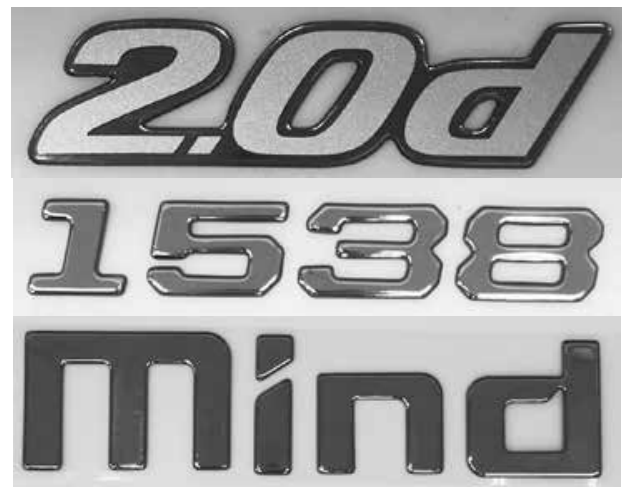

図 8 立体軟質マーク「ハイボスカル ${ }^{\circledR}$

ク，グレードマークが主流だが小ロット多品種対応，金型作 製リードタイム・環境対応 (VOCフリー) 等の面より採用が 増加している。

開発した蒸着フィルムをベース基材フィルム $(1 \sim 2 \mathrm{~mm})$ と積層し特殊抜き加工で端末に $\mathrm{R}$ 加工を施し，より立体感 のあるマークで更に表面にスクリーン印刷・エンボス加工に て意匠表現拡大を計っている。構成及び加工プロセスを図 9 に示す。

射出成形に比べ射出金型を使用せず安価な準備費, 生産 リードタイムの短縮, 小ロット対応, 曲面追従性が高いため 異曲率の被着体に同一マークで適用が可能で, マークの共通 化にも寄与できる。表面加飾処理の一環としてウレタン系ク 


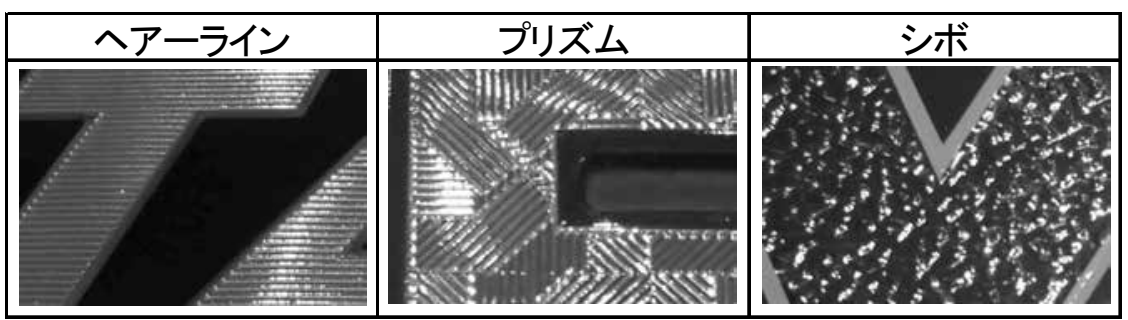

図 10 表面加工の例

マーク構成

\begin{tabular}{|c|}
\hline 印刷、エンボス加 \\
\hline 蒸着フイルム \\
\hline 接着剂 \\
\hline ベース基材 \\
\hline 両面テープ \\
\hline
\end{tabular}

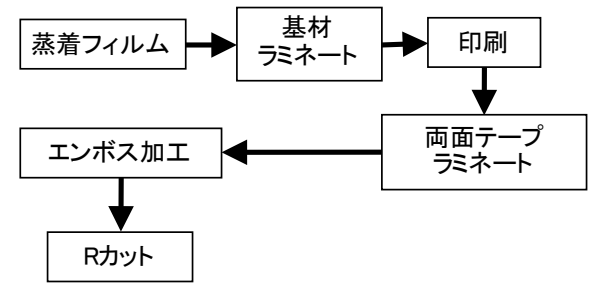

図 9 構成と加工プロセス

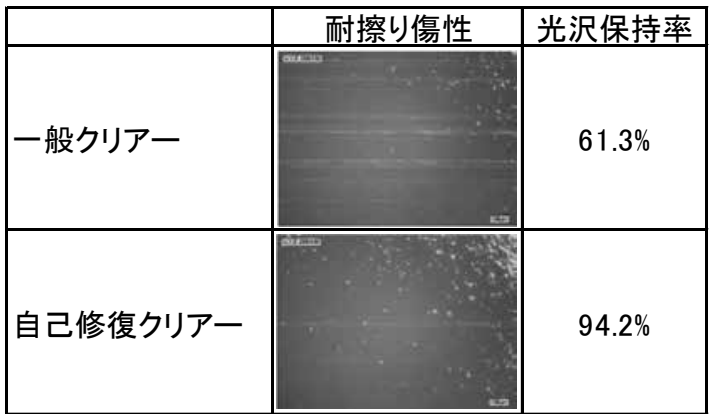

図 11 一般タイプと自己修復クリアー比較

リアーへのグロスコントロール率及びテクスチャービーズを 配合し光沢バリエーションの拡大も可能である。

またエンボス型を使用し表面に熱・圧力にてエンボス加工 を施すことにより，微細なパターン(ヘアーライン，プリズム， シボパターン)を小ロットで処理も可能であり耐熱, 耐候後 のエンボス保持性も優れている(図 10)。

最近，耐擦り傷性向上を目的としてゴム弾性ポリマー, リ ングポリマーをウレタン骨格レジンに配合した自己修復クリ アーも開発し本金属調マークに塗工し市場耐擦り傷性のレベ ルアップも可能である(図 11)。

最近マーク以外にセンタクラスタ, リアバンパーガーニッ シュ加飾, サイドステップガーニッシュ等の大型射出成形品 の代替として，VOCフリー・めっきフリー部品として金属 調ハイボスカルの採用が多数見受けられる。またその他金属 調フィルム適用事例として, スピードメーターダイヤル銘板

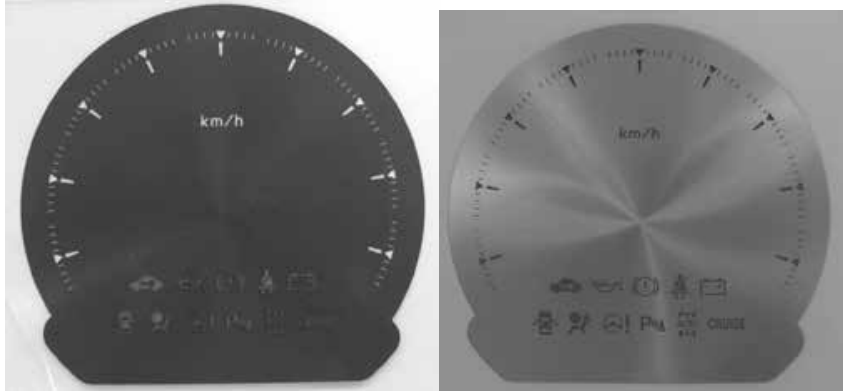

図 12 表面加工の事例

への PC シート + Ni スパッタへの UV 硬化樹脂のスピン調 パターン転写でのハーフミラーダイヤル及びエンジンネーム プレートにおけるへアーライン加工蒸着 PET シートへの印 刷等多数市場にて実績がある。（図 12 加飾品事例）

\section{4.おわりに}

金属調加飾の加工プロセスにおいては，コーティング滖の UV 化, LED-UV 化による乾燥工程の工数削減 · 省エネ化, フィ ルムインサート，インモールド転写成形による $\mathrm{CO}_{2}$ 削減，金 属代替としての軽量化での燃費向上, 六価クロム代替による 環境に配慮した取組みなど今後も更に継続されると思われる。

金属調フィルムにおいても加飾・機能面でのニーズの多様 化に対応し進化が計られ，グローバル展開でのコストダウン 材料に適合した加工プロセス (成形, トリミング) も更に深化 すると思われる。

弊社も今後継続的に環境に配慮し社会情勢，環境の変化に 柔軟に対応し物づくりイノベーションの一環として提供価值 の高い材料・技術を創製していく。

(Received March 30, 2016)

\section{参考資料}

1 ）山田隆一他; 熱可塑性樹脂成形体, 特許第4302282号 (2009).

2 ) 神谷達志他; 立体表示用構造体, 特許第3462047号 (2003).

3 ) 名古屋市工業研究所; 技術の広場, 7月号 (2015). 